\title{
V-VI KLASIŲ MOKINIŲ INTERESO KŪNO KULTŪRAI LYGIŲ KAITA
}

\author{
Lina Bagdonienė, Vincentas Blauzdys \\ Vilniaus pedagoginis universitetas, Vilnius, Lietuva
}

\begin{abstract}
Lina Bagdonienè. Vilniaus pedagoginio universiteto socialinių mokslų doktorantė. Mokslinių tyrimų kryptis — kūno kultūros ugdymo bendrojo lavinimo mokykloje problematika.
\end{abstract}

Vincentas Blauzdys. Socialinių mokslų (edukologijos) daktaras.Vilniaus pedagoginio universiteto Kūno kultūros teorijos katedros docentas. Mokslinių tyrimų kryptis — kūno kultūros ugdymo bendrojo lavinimo mokykloje problematika, kūno kultūros teorijos didaktika.

\section{SANTRAUKA}

Straipsnyje analizuojama V-VI klasiu mokiniu interesas kūno kultūrai, intereso lygiai ir ju kaita eksperimento laikotarpiu. Tyrimo objektas - V-VI klasiu mokiniu interesas kūno kultūrai. Tyrimo rezultatai gauti apklausos būdu atlikus ugdomaji pedagogini eksperimenta. Buvo tiriami dvieju Vilniaus miesto bendrojo lavinimo viduriniu mokyklu 346 penktu (10-11 metu) ir šeštu klasiu (11-12 metu) pagrindinès medicininès fizinio pajègumo grupès mokiniai. Šios apklausos metu buvo analizuojami ne tik tiesioginiai atsakymai, bet ir išskirti paaugliu domejjimosi kūno kultūra lygiai (Kregždè, 1988). Klasifikacijos pagrinda sudarè žmogaus veiklos aktyvumo charakteristikos ir intereso struktūrinès ypatybès.

Tyrimo rezultatai parodè, kad V-VI klasiu eksperimentiniu grupiu mokiniu interesas kūno kultūrai, jo lygiai prieš ugdomajį eksperimenta buvo panašūs, o po eksperimento statistiškai patikimai kito tik poveikio klasése ( $p<0,02$; $p<0,04)$, t. y. iš ,,vartotojo “ lygio perèjo į aukštesni — ,veikejo “, šiek tiek padaugejo „, specialiojo intereso “ lygio mergaičiu ir berniuku.

Raktažodžiai: kūno kultūros pamoka, interesas kūno kultūrai, kaita.

\section{IVADAS}

$\mathrm{D}$ abartinejje Lietuvos bendrojo lavinimo mokykloje mokiniai sutelktinai mokomi siekti jiems svarbiu pedagoginiu, socialiniu tikslų ir skatinami igyti kompetencijų, žinių bei gebejjimu, kurie būtu jiems prasmingi, t. y. atitiktu interesus ir poreikius, padètu rengtis suaugusiuju gyvenimui. Šie teiginiai įterpti i pagrindinį $\mathrm{V}-\mathrm{X}$ klasių mokinių kūno kultūros tikslą ir nusakyti fizinio ugdymo didaktinèse nuostatose: „Čia labai svarbu toliau ugdyti teigiamą požiūri (nuostata) i kūno kultūros pamokas, namų užduotis, padèti moksleiviui suvokti jų teikiamą ìvairiapusę - pedagoginę, fiziologinę ir socialinę - naudą, poveiki psichikai" (Bendrosios programos ir išsilavinimo standartai, 2003). Tokiai programinei nuostatai pritaria daugelis sporto edukologų, todèl siekiama, kad nuo fiziniu gebejjimu ir funkcinių galių stiprinimo būtų einama link vertybiniu orientacijų formavimo, tikslingu interesų skatinimo, teigiamo požiūrio ị kūno kultūros pamokas bei apskritai ị kūno kultūrą ugdymo (Feingold, Barrete, 1991; Blauzdys, 2002; Katinas, Vilkas, 2002). Taigi matyti, kad pokyčiai, vykstantys Lietuvos švietimo sistemoje, turi įtakos ịvairiu 
Žmogaus veiklos sričių pertvarkai bei asmens požiūriui, motyvacijai, domėjimuisi asmeninio bei visuomeninio gyvenimo reiškiniais ir jų kaita.

Interesas pagal Sporto terminų žodyną (2002) emocinè pažinimo poreikio apraiška, poreikis sužinoti, susipažinti. Tai dalykai, ị kuriuos žmogus linkęs kreipti dèmesi arba laikyti juos sąmonèje. Interesas lemia žmogaus veiklos motyvus ir yra svarbus motyvacijos veiksnys (Jovaiša, 2001).

Mokslinejje literatūroje terminas interesas dažniausiai analizuojamas motyvacijos aspektu. R. A. Pilojanas (Пилоян, 1984), J. Palaima (1987), E. L. Deci, R. M. Ryan (1991), N. I. Ponomariovas, V. M. Reizinas (Пономарёв, Рейзин, 1993), A. F. Spencer (1996), S. Fisher (1998), N. Koivula (1999), tyrę mokinių motyvacija kūno kultūrai, sportui, ivvairiai analizavo interesų ir poreikiu formavimą. E. P. Iljinas (Ильин, 2002) teigia, kad motyvai gali būti susiję su aktyvios veiklos procesu arba veiklos rezultatu. Pirmuoju atveju žmogaus tikslas yra tenkinti fizinio aktyvumo poreikị, patirti ispūdžių. Antruoju - siekiama save tobulinti, išreikšti ir itvirtinti, patenkinti materialius bei dvasinius poreikius ir pan. J. Armonienè (1998) teigia, kad interesas fizinèms pratyboms gali pasireikšti ivairiu intensyvumu - nuo to priklauso jo veiksmingumas, t. y. motyvacijos stiprumas. K. Kardelis (Кардялис, 1990) įrodè, kad veiksmingomis poveikio priemonèmis galima daryti ittaką mokiniu požiūriui i kūno kultūra, tačiau V-VI klasių mokinių interesas kūno kultūrai pagal S. Kregždès (1988) i̇vardytus ,specialaus intereso“, „veikejjo“, „vartotojo“ lygius nèra tirti.

Tyrimo tikslas - nustatyti V-VI klasiuc mokinių interesą kūno kultūrai, jo lygius (Kregždè, 1988) ir kaitą eksperimento laikotarpiu.

Tyrimo subjektas - dviejų Vilniaus bendrojo lavinimo mokyklų V-VI klasių mergaites ir berniukai. Objektas - V-VI klasiu mokiniu interesas kūno kultūrai.

Siekiant tikslo, buvo iškelti šie uždaviniai:

1) nustatyti ir palyginti tiriamujų mergaičių ir berniukų interesą kūno kultūrai, sportui prieš ir po ugdomojo pedagoginio eksperimento;

2) nustatyti tiriamų mergaičiu ir berniukų intereso kūno kultūrai lygius (Kregždè, 1988) prieš ugdomaji pedagogini eksperimentą ir po jo.

Tyrimo tikslo ir uždavinių sprendimo logika bei epistemologija buvo grindžiama normatyvine socialinių mokslų paradigma, besiremiančia kiekybiniu požiūriu ỉ tyrimą, kurio mokslinę vertę nusako kiekybiniai rodikliai, t. y. bandymas ¡žvelgti tiriamu požymių dèsningumus tiriamujų grupèse.

\section{TYRIMO METODIKA IR ORGANIZAVIMAS}

Ugdomajam eksperimentui vykdyti buvo sudarytos dvi priklausomos imtys, kurias sudare 346 pagrindinès medicininès fizinio pajègumo grupès penktų (10-11 metų) ir šeštu klasių (11-12 metu) mokiniai (178 berniukai ir 168 mergaitès; žr. lent.), parinkti netikimybiniu (neatsitiktiniu) būdu iš dviejų Vilniaus bendrojo lavinimo mokyklų. 1999-2000 m. m. iš penkių V klasių buvo sudarytos viena eksperimentine (E 1) ir viena kontrolinè (E 2) grupè. 2000-2001 m. m. eksperimentas tęstas ten pat jau šeštose klasèse.

Atlikus eksperimenta V klasèse, programa buvo šiek tiek patikslinta ir, remiantis 19992000 mokslo metu eksperimento metodikos ir rezultatu analize, pakartota $2000-2001 \mathrm{~m}$. m. kitoje Vilniaus bendrojo lavinimo mokykloje, kurioje iš keturių V klasių sudarytos taip pat viena eksperimentine (E 3) ir viena kontrolinè (E 4) grupè. Eksperimentas buvo atliekamas realiomis ugdymo salygomis $(1999-2000 \mathrm{~m}$. m. mūsų šalies penktujų klasių mokiniai pradejjo mokytis pagal reformuotos mokyklos programas ir vadovèlius).

Šio amžiaus grupès mokiniu pasirinkimą lèmè ankstesnių tyrimų duomenys (Goštautas, Kardelis, 1991), bylojantys apie tai, kad norint paskatinti aktyvią vaikų fizinę veiklą būtina juos tinkamai mokyti kūno kultūros iki penktos, šeštos klasès, kol jų domèjimasis ta veikla laisvalaikiu dar nepradejo mažèti. Be to, šiuo amžiaus tarpsniu formuojasi bendra asmenybès saviugdos sistema, kuriai būdinga savianalizè, tikslų iškèlimas, savikontrolè, fizinio išsivystymo koregavimas ir kt. Šie teiginiai ir lèmé, kad ugdomajam eksperimentui buvo pasirinkti penktų ir šeštų klasiu mokiniai, o remiantis 1995 m. Lietuvos Respublikos kūno kultūros ir sporto įstatymo 21 straipsniu, apibrēžiančiu privalomų kūno kultūros ir sporto pratybu skaičiu, visose eksperimente dalyvaujančiose klasėse buvo organizuotos po tris savaitines kūno kultūros pamokas.

Remiantis 1998 m. spalio mèn. 192 mokiniu anketinès apklausos metu pareikšta nuomone, sudaryta kūno kultūros pamokų pedagoginị ir socialini 


\begin{tabular}{|c|c|c|c|c|c|c|}
\hline Grupès & \multicolumn{2}{|c|}{ E 1 } & \multicolumn{2}{c|}{ E 2 } & E 3 & E 4 \\
\hline Klasės & V & VI & V & VI & V & V \\
\hline Mergaitès (n) & 24 & 24 & 41 & 40 & 23 & 16 \\
\hline Berniukai (n) & 28 & 28 & 37 & 37 & 21 & 27 \\
\hline
\end{tabular}

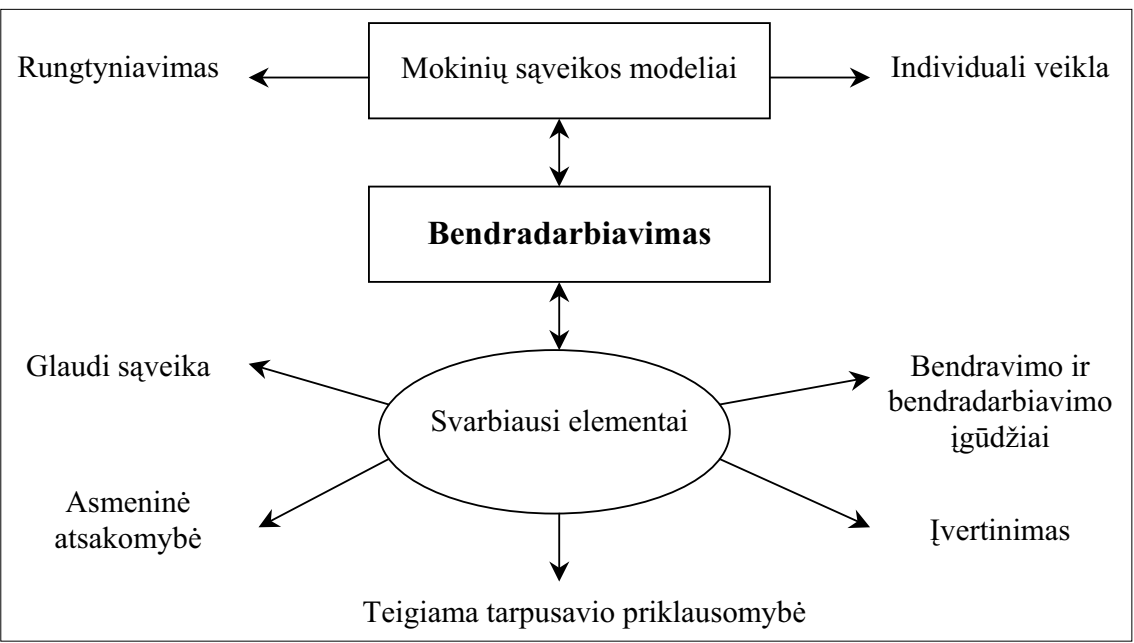

Lentelè. Tiriamųjų kontingento charakteristika

Pastaba. Grupès: E 1, E 3 - eksperimentinès; E 2, E 4 - kontrolinès.

1 pav. Mokymosi bendradarbiaujant apibendrinta schema (Benett et al., 2000)

prasmingumą didinanti metodika, kuri taikyta E 1 ir E 3 grupèse. Šiu grupių klasėse buvo dirbama pagal mūsų sudarytas eksperimentines V-VI klasių kūno kultūros programas ir kūno kultūros pamoku prasmingumą didinančią metodiką. E 2 ir E 4 grupès V-VI klasių mokiniai mokèsi pagal tų pačių eksperimentinių kūno kultūros programų lengvosios atletikos, gimnastikos, sportinių žaidimų, sparčiojo žygio turinius, tačiau skyrèsi žinių temos (nebuvo integruotų žinių temų) ir fizinio ugdymo(si) metodika. Kūno kultūros programos parengtos remiantis Lietuvos bendrojo lavinimo mokyklos bendrosiomis programomis (1997), Bendrojo išsilavinimo standartais (1997), Bendrojo lavinimo mokyklos V-XII klasių kūno kultūros programomis (1992). Mūsu kūno kultūros programu tikslas — ugdyti kūno kultūros, kaip bendrosios kultūros dalies, suvokimą, sąmoninga asmens požiūrị i kūno kultūrą ir jos puoselèjimą. E 1 ir E 3 grupèse pagal pamokos uždavinius, žinioms buvo skiriama vidutiniškai 4-6 minutès (parengiamojoje pamokos dalyje $-1-3 \mathrm{~min}$, pagrindineje $-4-7 \mathrm{~min}$, baigiamojoje $-1-$ 2 min; išimtis -integruotos teorinès pamokos, kurių trukmè - 45 min) pamokos laiko. Ju metu buvo aiškinama apie fizinių pratimu paskirti ir svarbą paauglio sveikatai, jų poveiki organizmui. Be to, šiose klasèse per kūno kultūros pamokas buvo daugiau dirbama asmenybès ugdymo kryptimi taikant bendradarbiavimo metodą: kūno kultūros ir socialiniai gebejjimai plètojami tiesioginio mokinių bendradarbiavimo, individualios atsakomybès ir teigiamos tarpusavio priklausomybès dèka. E 1 ir E 3 klasių grupelèse buvo dirbama atsižvelgiant i pirmame paveiksle pateiktus mokymo(si) bendradarbiaujant principus.

Taip pat remtasi L. Šiaučiukėnienès (1997) sudarytomis taisyklemmis, kurios pritaikytos fiziniam mokinių ugdymui: atsižvelgiant ị VI klasès mokinių amžiaus tarpsnio, lyties ir kiekvieno mokinio fizinio pajègumo ypatumus, išnaudoti pratimu technikos mokymo ir fiziniu ypatybių diferencijavimo galimybes stiprinant motyvaciją; diferencijuojant mokyma, padèti ugdytiniui pažinti save, suvokti savo galimybes, kelti aspiraciju lygi, ugdyti poreiki nuolat mokytis ir tobulèti; leisti kiekvienam dirbti pagal gebejjimus, savu tempu, stengtis nepervargti, nebijoti; domètis besimokančiojo asmenybe, elgtis taip, kad jis jaustu geranoriška pedagogo pagalbą; parinkti diferencijuotas individualias ar grupines mokymosi ir fizinių ypatybių lavinimo užduotis, kad kiekvienas galètų pasireikšti, kad atsirastų sėkmès motyvas. Atsižvelgta ir i V. Lepeškienès (1996) rekomendacijas mokinių savigarbai stiprinti.

E 2 ir E 4 grupèse pagal pamokos uždavinius, žinioms buvo skiriama vidutiniškai $1-3$ minutès (parengiamojoje pamokos dalyje $-1-2 \mathrm{~min}$, pagrindineje - iki $3 \mathrm{~min}$, baigiamojoje - iki $1 \mathrm{~min}$ ) pamokos laiko. Šiu klasių grupelių veikla buvo daugiau pagrista konkuravimu (lenktyniavimu (kas greičiau atliks) ir individų ambicinga raiška). 
Tyrimo metodai: mokslinès literatūros teorinè analizè, ugdomasis pedagoginis eksperimentas, anketinè apklausa, matematinè statistika. Duomenu matematinè statistinè analizè atlikta naudojant SPSS PC / 8.0 (Statistical Package for the Social Sciences, SPSS X, 1984) statistini paketa. Lyginant kokybinius požymius, taikytas chi kvadrato $\left(\chi^{2}\right)$ kriterijus. Statistinè išvada pripažinta patikima, kai pasikliovimo lygmuo $\mathrm{p}<0,05$.

Duomenų rinkimo procedūra. Mokinių anketinei apklausai vykdyti buvo gautas mokyklu vadovybès sutikimas. Apklausos metu vadovautasi geravališkumo, etiniais ir teisiniais tyrimo principais, t. y. nesiekiant tiriamiesiems padaryti nei psichinès, nei moralinès žalos ir garantuojant tyrimo duomenu anonimiškumą. Apklausa atlikta vienu metu klasejje dalyvaujant tyrejui (kad iškilus klausimams ir neaiškumams tiriamieji galètu gauti tiesiogini atsakyma). Laiko atsakymams buvo skiriama tiek, kiek reikejo patiems tiriamiesiems, tačiau tam pakako vienos pamokos.

Visi tyrimo dalyviai buvo informuoti apie tyrimo tiksla, jo anonimiškumą ir supažindinti su anketos pildymo instrukcija. Jų buvo paprašyta i klausimus atsakinèti sąžiningai ir savarankiškai.

\section{REZULTATAI}

Eksperimento pradžioje ir pabaigoje V ir VI klasių mokinių klausème: „Kuo reiškiasi Tavo domejjimasis sportavimu (ar mankštinimusi)?“ Buvo analizuojami ne tik tiesioginiai atsakymai, bet ir, remiantis S. Kregždès (1988) rekomendacijomis, išskirti paauglių intereso kūno kultūrai lygiai. Klasifikacijos pagrindą sudarè žmogaus veiklos aktyvumo charakteristikos ir interesu struktūrinès ypatybès.

Tyrimo rezultatai parodè: eksperimento pradžioje $91,67 \%$ E 1, 78,05\% E 2, 73,91\% E 3, $81,25 \%$ E 4 mergaičiu ir $89,29 \%$ E $1,83,78 \%$ E 2, 80,95\% E 3, 77,78\% E 4 berniuku teigè, kad jų domèjimasis kūno kultūra ar sportu pirmiausia reiškiasi varžybu žiūrējimu per televiziją. $91,67 \%$ E $1,37,50 \%$ E $2,86,96 \%$ E 3, 75,00\% E 4 mergaičiu ir $71,43 \% \mathrm{E} 1,75,67 \%$ E 2, 61,90\% E 3, 70,37\% E 4 berniukų žiūri mokyklos sporto renginius. Daugelio paauglių domèjimasis perauga i jų pačių aktyvią fizinę veiklą. Mažiau nei pusė E 1, E 2, E 3 ir daugiau nei pusè E 4 mergaičiu bei daugiau nei pusè visų grupių berniukų lanko ivvairius sporto būrelius. Mažiau nei trečdalis E 1, mažiau nei pusè E 2, E 3 ir beveik du trečdaliai E 4 mergaičių bei mažiau nei pusè E 1, E 3 ir daugiau nei pusė E 2, E 4 berniukų dalyvauja varžybose. Daugiau nei pusè visu grupių mergaičiu ir E 3, E 4 berniukų bei mažiau nei pusè $\mathrm{E} 1$, E 2 berniuku mankštinasi, nes nori turèti gražų kūną. Galima daryti išvadą, kad šio amžiaus paaugliai jau turi sąmoningą savo fizinès veiklos tikslą.

Eksperimento pabaigoje nustatyta, kad E 1 labai sumažéjo mergaičiu $\left(\chi^{2}=4,55\right.$; df 1 ; $\mathrm{p}<0,03 ; \mathrm{C}=0,29)$ ir berniuku $\left(\chi^{2}=4,91\right.$; df 1 ; $\mathrm{p}<0,03 ; \mathrm{C}=0,28)$, žiūrinčių varžybas per televizija ir ívairius mokyklos sporto renginius $\left(\chi^{2}=15,39 ;\right.$ df $1 ; \mathrm{p}<0,0001 ; \mathrm{C}=0,49 ; \chi^{2}=4,67 ;$ df $1 ; \mathrm{p}<0,03 ; \mathrm{C}=0,28)$, tačiau gerokai daugiau E 1 mergaičiu $\left(\chi^{2}=4,00 ;\right.$ df $\left.1 ; \mathrm{p}<0,05 ; \mathrm{C}=0,28\right)$ ir berniuku $\left(\chi^{2}=6,84 ;\right.$ df $\left.1 ; \mathrm{p}<0,01 ; \mathrm{C}=0,33\right)$ bei E 2 berniuku ( $\chi^{2}=4,59 ;$ df $\left.1 ; \mathrm{p}<0,03 ; \mathrm{C}=0,24\right)$ pradejo dalyvauti mokyklos sporto renginiuose ar varžybose. Eksperimento pabaigoje E 1 mergaičiuc, besimankštinančių savarankiškai ir norinčių stiprinti sveikata, buvo kur kas daugiau $(p<0,05)$ nei tos pačios grupès berniukų, labai smarkiai $(p<0,005)$ sumažèjo $E 2$ berniukų nei tos pačios grupès mergaičių. Labai $(p<0,04)$ sumažèjo sportuojančių E 2 mergaičių, teigiančių, kad jos sportuoja dèl to, kad gerintų fizini parengtuma, nei tos pačios grupès berniukų. VI klasès mokslo metú pabaigoje statistiškai labiau $(\mathrm{p}<0,05)$ padaugèjo E 1 mergaičių, pradejjusių mankštintis (nes jos norèjo turèti gražų kūna), nei tos pačios grupès berniukų ir E 2 mergaičiu $\left(\chi^{2}=5,43\right.$; df 1 ; $\mathrm{p}<0,02 ; \mathrm{C}=0,28)$.

Eksperimento pradžioje pagal anketinès apklausos duomenis pirmam — „vartotojo“ — lygiui priskirti daugiau nei du penktadaliai E 1, E 2 mergaičių ir berniukų bei daugiau nei trečdalis E 3, E 4 mergaičių ir berniuku (2 pav.). Šie mokiniai teige, kad jie sportu domisi tik žiūrèdami varžybas per televizija, mokyklos sporto renginius. Eksperimento pabaigoje statistiškai reikšmingai sumažèjo tą teigiančiu E 1 mergaičiu $\left(\chi^{2}=5,84\right.$; df $1 ; \mathrm{p}<0,02 ; \mathrm{C}=0,14)$ ir berniuku $\left(\chi^{2}=4,14\right.$; df $1 ; \mathrm{p}<0,04 ; \mathrm{C}=0,11)$. Nustatytas statistiškai reikšmingas skirtumas tarp E 1 ir E 2 mergaičiuc, priklausančių šiam lygiui, kadangi E 2 mergaičių skaičius liko panašus, o E 1 jų labai sumažejo $(\mathrm{p}<0,02)$.

Antram — „veikèjo“ - lygiui eksperimento pradžioje priskirta mažiau nei ketvirtadalis E 1, E 2 mergaičių ir E 3 berniukų bei ketvirtadalis ar šiek tiek daugiau nei ketvirtadalis E 3, E 4 mergaičių ir E 1, E 2, E 4 berniukų (2 pav.). Antro 


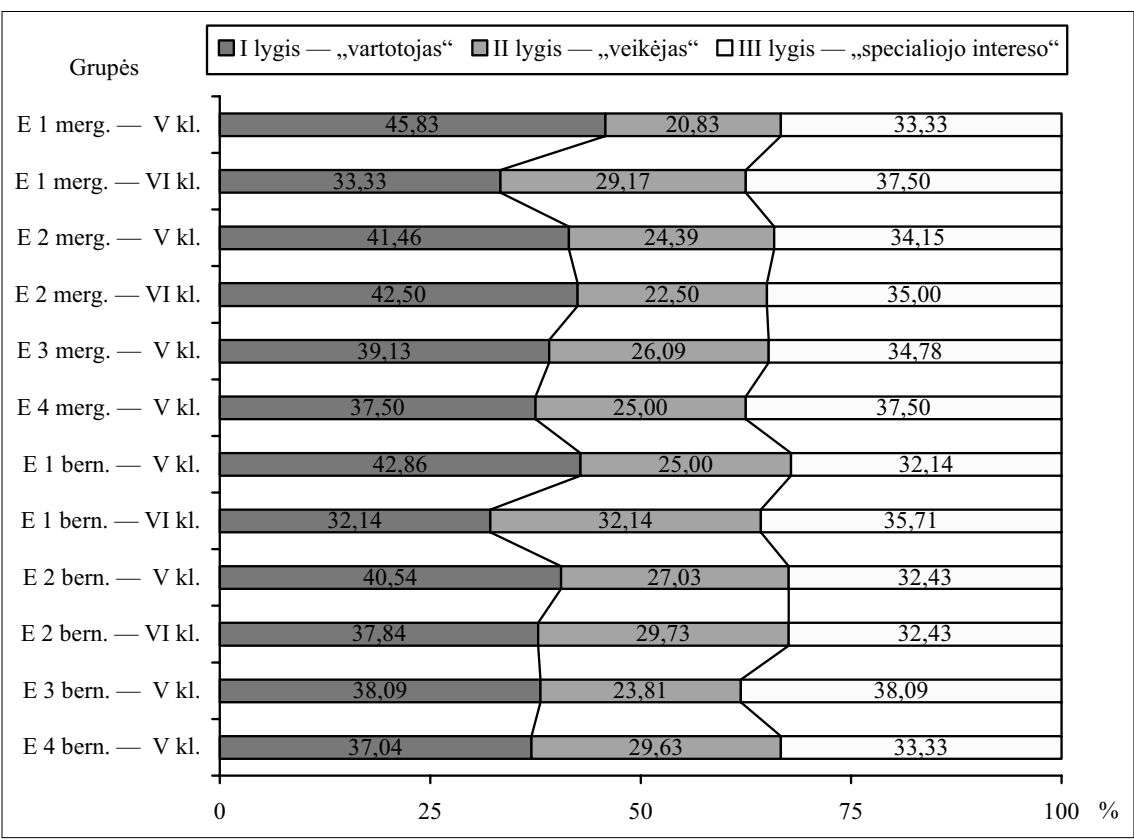

2 pav. Penktų ir šeštų klasių mokinių intereso kūno kultūrai ir sportui lygių procentinis skirstinys bei interesų lygių kaita eksperimento laikotarpiu

tyrimo metu paaiškejjo, kad E 1 grupèje šio lygio mergaičiu šiek tiek padaugejjo (nuo 20,83 iki $29,17 \%$ ), o E 2 sumažèjo (nuo 24,39 iki 22,50\%). Statistiškai reikšmingai padidejo E 1 ,veikèjo“ lygio berniukų skaičius ( $\chi^{2}=4,19$; df $1 ; p<0,04$; $\mathrm{C}=0,11)$, o $\mathrm{E} 2$ tokių išliko mažiau nei trečdalis $(29,73 \%)$ berniuku.

Trečiam - „specialiojo intereso“ - lygiui eksperimento pradžioje priskirta trečdalis E 1, E 2, E 3, E 4 mergaičiu, apie trečdali E 1, E 2, E 4 ir daugiau nei trečdalis E 3 berniuku (2 pav.). Eksperimento pabaigoje nustatyta, kad tokiu E 1 mergaičių šiek tiek padaugèjo, E 2 mergaičių skaičius išliko panašus, o E 1 berniukų nedaug padaugejjo, E 2 jų skaičius nepakito.

Palyginus V ir VI klasių tų pačių mokinių intereso kūno kultūrai lygius, nustatytas statistiškai reikšmingas skirtumas. Kur kas daugiau E 1 mergaičiu $\left(\chi^{2}=5,84 ;\right.$ df $\left.1 ; \mathrm{p}<0,02 ; \mathrm{C}=0,14\right)$ ir berniuku $\left(\chi^{2}=4,14\right.$; df $\left.1 ; \mathrm{p}<0,04 ; \mathrm{C}=0,11\right)$ is „vartotojo“ lygio perèjo i̇ „veikèjo“. VI klasejje labiau sumažejo „vartotojo“ lygio E $1\left(\chi^{2}=4,90\right.$; df $1 ; \mathrm{p}<0,03 ; \mathrm{C}=0,11)$ nei E 2 mergaičiu skaičius. Taigi nors ir nedaug, tačiau nuo 33,33 iki 37,50\% padaugejo „specialiojo intereso“ lygio E 1 mergaičiu ir nuo 32,14 iki 35,71\% berniukų. E 2 pirmo lygio mergaičiu liko beveik tiek pat $(42,50 \%)$, o berniukų sumažèjo nuo 40,54 iki $37,84 \%$. Antro lygio mergaičių sumažèjo nuo 24,39 iki $22,5 \%$, o berniukų padaugejo nuo 27,03 iki $29,73 \%$. Trečio lygio mergaičiu $(35,00 \%)$ ir berniukų $(32,43 \%)$ situacija nepasikeitè (2 pav.).

\section{REZULTATUQ APTARIMAS}

I. Zuozienė (1998), S. Fisher (1998), G. Levickienė (1999), G. Levickienė, K. Kardelis (1999), N. Koivula (1999) tyrimais nustatè, kad šio amžiaus mokinių fizinę saviraišką, interesus, ypač mergaičiu, stipriausiai motyvuoja sveikatingumo motyvai. Kiek mažiau reikšmingi laimejjimu motyvai, iš kurių išsiskiria noras nugaletti varžybose, tobulos išvaizdos siekimas. Tyrimo rezultatai parodé, kad daugiau nei puse abieju grupių mergaičių ir berniukų mankštinosi dèl to, kad stiprintų sveikata, gerintų fizini parengtumą. Taip pat šiuo amžiaus tarpsniu jiems pasidare svarbūs pasiekimų (noras laimèti varžybas), malonumų (noras smagiai leisti laisvalaiki) ir bendravimo (galimybė rasti draugų) motyvai. Mergaites dažniausiai skatino noras gražiai atrodyti, o berniukus - smagiai leisti laisvalaiki ir laimėti varžybas. Šiuo klausimu mūsų tyrimo duomenys yra artimi P. Markon, R. Thibeault, R. Guenette, A. Dorion (1993), I. J. Zuozienès (1998), N. Koivulos (1999), S. Guskovo, A. Zotovo (Гуськов, Зотов, 2001) tyrimu duomenims. I. Rovengno, D. Bandhauer (1997) teigia, kad labiausiai mokinių požiūri i fizini ugdymą(si) veikia vidiniai motyvai, tokie kaip smalsumas, interesas, savo vidinio „aš“ nugalèjimas. L. Jovaiša (2001) pažymi: jei motyvai pripažįstami, dar nereiškia, kad jie bus igyvendinami. Autoriaus nustatyta, kad konkrečiai veiklai skatina tik tie motyvai, kurie 
yra isisąmoninti. Eksperimento metu svarbiu veiksniu E 1 grupés ugdytiniams tapo noras prasmingai mankštintis.

S. Kregžde (1988) ir E. L. Deci, R. M. Ryan (1991) pabrèžia, kad netgi kai žmogaus veikla prasideda dar neturint intereso ir šis susiformuoja pačios veiklos procese, būtinos tokios situacijos, kurios patrauktų ji kažkuo nauju, nepaprastu, ko nežinojo ir nelaukè šioje veikloje. Tai „vartotojo“ intereso fazé. Toliau formuojantis interesui, veikiant emociniam pastiprinimui, turi susidaryti veiklios, aktyvios būsenos, būdingos „veikejjo“ intereso lygiui. Ir pagaliau, kai veikla tampa vertybe, žmogus pereina $\mathfrak{i}$,specialiojo intereso" fazę. Pirmieji du interesų lygiai tèra tik neišvengiamos intereso formavimo pakopos (jie gali būti pagrindas ir kitoms interesų rūšims atsirasti).

Apibendrinant „vartotojo“ lygi galima įvardyti, kad mūsų tirti paaugliai dažniausiai nesiima jokios aktyvios fizinès veiklos: nesimankština savarankiškai, nelanko jokių sporto būrelių ar treniruočių. Pasak S. Kregždès (1988), tokiems mokiniams būdingas nevalingas dėmesys fizinei veiklai, kuri organizuojama kitų. Jie turi teigiamu emocijų, tačiau jos yra be pastangu sukurti tokia situacija, kurioje pasikartotu. Paaiškeejo, kad tirtų paaugliu ,vartotojo“ lygio interesus daugelyje situacijų lemia išoriniai veiksniai. Šio lygio intereso charakteristika rodo silpną intelektini, emocini ir valios aktyvuma, o tai lemia intereso situaciškumą, nepastovumą.

Apibendrinant „,veikèjo“ lygi galima įvardyti, kad tirtieji paaugliai ne tik atitinka pirmo lygio interesų bruožus, bet jau yra pakankamai fiziškai aktyvūs: jie dalyvauja varžybose, mokyklos sporto renginiuose, lanko treniruotes, sporto būrelius ar mankštinasi savarankiškai. Pasak S. Kregždès (1988), šie paaugliai dar neturi savo fizinès veiklos sąmoningo pagrindimo, nèra išsikèlę sau siekiamo tikslo. Jie valingai skiria dèmesi veiklai, kurią organizuoja pats individas, deda aktyvias pastangas, siekia teigiamų emocijų ir sąmoningai bando jas pakartoti veiklos procese. Interesas jau gana pastovus, tačiau nesiejamas su vertybinėmis orientacijomis. Mokinys pats planuoja ir organizuoja veikla, kuri sukelia pasitenkinima. Tai vienas iš pagrindinių fizinès veiklos motyvų. Toliau autorius teigia, kad „,veikejjo“ lygio žmogus interesų turi daug mažiau, bet jų reikšmė poelgiui yra pastebimai didesnè, nes jie gerokai sustiprina asmenybès kryptingumą. $\mathrm{O}$ šis kryptingumas pasireiškia asmenybės poreikiais, potraukiais, interesais, polinkiais, siekiais, aspiracijomis, savęs vertinimu, issitikinimais, pasaulěžiūra visoje veiklos motyvacijos sistemoje.

Apibendrinant „specialiojo intereso“ lygi galima teigti, kad mūsų tirti paaugliai atitinka anksčiau minètų dviejų lygių apibūdinimus ir turi savo fizinès veiklos sąmoningą tikslą, kurio siekia. Jie aktyviai, valingai siekia teigiamų emocijų ir skiria nuolatinị dèmesị tai veiklai. Tai pasireiškia intensyviau, nes atsiranda įsisąmonintas apsisprendimas, perspektyva. Interesas tampa nuolatinis, apibendrintas, sąmoningai derinamas su kitomis apibendrintų interesų grupèmis ir vertybinemis orientacijomis.

Apibendrinti tyrimo rezultatai rodo, kad eksperimento pabaigoje procentiškai daugiau E 1 nei E 2 grupes mergaičiu ir berniukų buvo pakankamai fiziškai aktyvesni, daugiau jų lankè įvairius sporto būrelius, jie dažniau dalyvavo mokyklos sporto renginiuose, varžybose, geriau perprato fizinès veiklos naudingumą.

\section{IŠVADOS}

1. Nustačius tiriamujų grupių mokinių interesą kūno kultūrai prieš ugdomaji pedagogini eksperimenta galima teigti, kad šis jų interesas buvo panašus. Dažniausiai domėjimasis kūno kultūra, sportu reiškèsi mokyklos sporto renginių ar varžybų stebėjimu. Mažiau nei pusè apklaustų visų grupių mergaičiu ir šiek tiek daugiau nei pusè visų grupių berniukų lankè įvairius sporto būrelius.

2. Atlikus interesų analizę po ugdomojo pedagoginio eksperimento galima teigti, kad labai sumažèjo rečiau stebinčiu varžybas per televizija ir įvairius mokyklos sporto renginius E 1 mergaičiu $(p<0,03)$ ir berniuku ( $p<0,03)$, nes kur kas daugiau $\mathrm{E} 1$ mergaičiu $(\mathrm{p}<0,05)$ ir berniu$\mathrm{ku}(\mathrm{p}<0,01)$, E 2 berniukų $(\mathrm{p}<0,03)$ pradejo aktyviau dalyvauti ivvairiuose mokyklos sporto renginiuose ir varžybose.

3. Palyginus V ir VI klasių mokinių intereso kūno kultūrai lygius prieš ugdomaji eksperimentą ir po jo paaiškejjo, kad mergaičių ir berniukų interesų lygiai po eksperimento statistiškai patikimai kito tik poveikio klasėse $(\mathrm{p}<0,02$; $\mathrm{p}<0,04)$, t. y. iš „vartotojo“ lygio perèjo i aukštesni „veikèjo“ lygi, šiek tiek padaugejjo „specialiojo intereso“ lygio mergaičių ir berniuku. 


\section{LITERATŪRA}

Armonienè, J. (1998). Jaunimo fizinio aktyvumo ugdymo veiksniai. Vilnius: VU 1-kla.

Bendrojo išsilavinimo standartai (Tikslieji, gamtos mokslai, darbai ir buities kultūra, kūno kultūra): I-X klasès: projektas 2. (1997). Vilnius: ŠMM Leidybos centras.

Bendrojo lavinimo mokyklos V-XII klasiu kūno kultūros programos. (1992). Vilnius: ŠMM Leidybos centras.

Bendrosios programos ir išsilavinimo standartai. (2003). Vilnius: Švietimo aprūpinimo centras.

Bennett, B., Rolheiser-Bennett, C., Stevahn, L. (2000). Mokymasis bendradarbiaujant: kur jausmai ir protas susitinka. Vilnius: Garnelis.

Blauzdys, V. (2002). Naujoviška kūno kultūros pamoka: mokymo priemoné kūno kultūros specialybès studentams, magistrantams. Vilnius: VPU 1-kla.

Deci, E. L., Ryan, R. M. (1991). A motivational approach to self: Integration in personality. In R. Dientsbier (Ed.), Nebraska Symposium on Motivation, Vol. 38. Perspectives on Motivation (pp. 228-237). Lincoln: University of Nebraska Press.

Feingold, R. S. C. \& Barrete, G. T. (1991). Strategies for school fitness curriculum modifications: An integrative model utilizing the superordinate goal theory. Sport and Physical Activity, 12, 54-59.

Hand Dance, Fisher, S. (1998). Developing and implementing a K-12 character education program. Journal of Health, Physical Education, Recreation and Dance, Vol. 69, 2, 21-22.

Goštautas, A., Kardelis, K. (1991). Fiziškai aktyvios veiklos ir kitokio moksleivių socialinio elgesio kitimas priklausomai nuo amžiaus. Lietuvos medicina, 1, 3-8.

Jovaiša, L. (2001). Ugdymo mokslas ir praktika: analitiniu straipsniu monografija. Vilnius: Agora.

Katinas, M., Vilkas, A. (2002). 12-13 metų mergaičių koordinaciniu gebéjimo lavinimo per kūno kultūros pamokas priemoniu poveikis. Sporto mokslas, 2, 5962.

Koivula, N. (1999). Sport participation: Differences in motivation and actual participation due to gender typing. Journal of Sport Behaviour, Vol. 22 (3), 360.

Kregžde, S. (1988). Profesinio kryptingumo formavimosi psichologiniai pagrindai: monografija. Kaunas: Šviesa.

Lepeškienè, V. (1996). Humanistinis ugdymas mokykloje. Vilnius: Valstybinis leidybos centras.

Levickienė, G., Kardelis, K. (1999). Moksleivių fizinès saviugdos komponentų bei socialinių ir edukaciniu veiksnių sąsaja. Socialiniai mokslai, 4, 91-98.

Levickienè, G. (1999). Moksleiviu fizinè saviugda ir jos komponentai. II Lietuvos edukologijos doktorantu ir ju moksliniu vadovu konferencija: jaunuju mokslininku darbai (pp. 267-274). Kaunas: Technologija.

Lietuvos bendrojo lavinimo mokyklos bendrosios programos (I-X klasés). (1997). Vilnius: ŠMM Leidybos centras.

Lietuvos Respublikos kūno kultūros ir sporto įstatymas. (1996). Vilnius: RSISTC.

Markon, P., Thibeault, R., Guenette, R., Dorion, A. (1993).
A school program for the youth regularly and voluntary active. Lvairaus amžiaus žmoniu sveikos gyvensenos problemos, $120-127$.

Palaima, J. (1987). Fiziniu pratimu mokymo psichologijos pagrindai: mokymo priemone LVKKI studentams. Vilnius: Raidè.

Rovengno, I., Bandhauer, D. (1997). Psychological disposition that facilitated and sustained the development of knowledge of a constructivist approach to physical education. Journal of Vouching in Physical Education, Vol. 16, 136-154.

Spencer, A. F. (1996). Ethics in physical education and sport. Journal of Health, Physical Education, Recreation and Dance, Vol. 67, 7, 37-39.

Sporto terminu žodynas. (2002). Parengè St. Stonkus. T. 1. Kaunas: LKKA.

Šiaučiukėnienė, L. (1997). Mokymo individualizavimas ir diferencijavimas: monografija. Kaunas: Technologija.

Zuozienè, I. J. (1998). Kūno kultūros ir sveikos gyvensenos žiniu itaka moksleiviu fiziniam aktyvumui: edukologijos daktaro disertacija. Kaunas: LKKI.

Гуськов, С., Зотов, А. (2001). Почему школьники должны заниматься физической культурой? Специальный выпуск "Спорт для всех», 55-60.

Ильин, Е. П. (2002). Мотивачия и мотивы. СанктПетербург: Питер.

Кардялис, К. К. (1990). Педагогические основы информачионного воздействия на отношение школьников $к$ физкультурной-спортивной деятельности: афтореф. дис. на соиск. учён. степ. д-ра пед. наук. Каунас.

Пилоян, Р. А. (1984). Мотивачия спортивной деятельности. Москва: ФИС.

Пономарёв, Н. И., Рейзин, В. М. (1993). Некоторые асспекты формирования положитеьного отношения человека к физической культуре. Теория и практика физической культуры, 9-10, 8-11. 


\title{
CHANGE OF INTEREST LEVEL TOWARDS PHYSICAL EDUCATION IN SCHOOLCHILDREN OF FORMS V-VI
}

\author{
Lina Bagdonienė, Vincentas Blauzdys \\ Vilnius Pedagogical University, Vilnius, Lithuania
}

\begin{abstract}
The article provides the analysis of students' (forms V-VI) interest in physical education, also the level of such interest and its change during the period of the experiment. The research object is the interest of students of forms $\mathrm{V}-\mathrm{VI}$ in physical education. The research results obtained by the questionnaire interrogation of 346 pupils of the fifth (aged 10-11) and sixth (aged 11-12) forms from two secondary education schools of Vilnius, having applied the pedagogical experiment. The participants of the experiment were the students of medical group of physical preparedness. The questionnaire aimed at both analyzing direct answers and establishing the levels of teenagers' interest in physical education (Kregždè, 1988). The classification was based on the peculiarities of personality activity characteristics and structural features of interest.

The research results showed similarity between the students from experimental groups (forms $\mathrm{V}-\mathrm{VI}$ ) interest in physical education and its level before the experiment. Statistical difference was established only in the classes of influence $(p<0.02 ; p<0.04)$, i. e., the level has moved up from the "consumer" to the higher one - the "performer". The number of boys and girls of "special interest" has increased slightly.
\end{abstract}

Keywords: physical education lesson, interest in physical education, change.

Gauta 2005 m. vasario 28 d.

Received on February 28, 2005

Priimta 2005 m. lapkričio 16 d. Accepted on November 16, 2005

\author{
Lina Bagdoniené, Vincentas Blauzdys \\ Vilniaus pedagoginis universitetas \\ (Vilnius Pedagogical University) \\ Studentų g. 39, LT-08106 Vilnius \\ Lietuva (Lithuania) \\ Tel +370 52752225 \\ E-mail kkteor@vpu.lt
}

